\title{
Treatment of idiopathic hypercalciuria and its impact on associated diseases
}

\author{
Miguel Liern, M.D., ${ }^{a}$ Mónica Bohorquez, M.D. ${ }^{a}$ Graciela Vallejo, M.D. ${ }^{a}$
}

\begin{abstract}
Idiopathichypercalciuria may be associated with urinary tractinfection, hematuria, nephrolithiasis and osteopenia. In order to describe the occurrence of these concurrent conditions related to the variation in urinary calcium and hypercalciuria response to sequential therapy, with a normal protein and low sodium diet, potassium citrate and hydrochlorothiazide; 46 patients older than 4 years, with no urinary tract diseases, sphincter control and normal blood creatinine values were followed-up during 43 months. Hypercalciuria was seen to be associated with kidney stones (EAR 47\%; RR 3.3), hematuria (EAR 71\%; RR 2.5), urinary tract infections (EAR 57\%;RR3), and osteopenia (EAR 33\%; RR 3).

A normal value of urinary calcium was achieved with sequential therapy in 43 patients, but during follow-up 32 patients discontinued treatmentand hypercalciuria recurred in $44 \%$ of them, in association with hematuria and urinary tract infection. Conclusions. Sequential therapy reduced hypercalciuria and the incidence of associated diseases.
\end{abstract}

Key words: hypercalciuria, hematuria, urinary tract infection, osteopenia, nephrolithiasis.

http:/ /dx.doi.org/10.5546/aap.2013.110

\section{INTRODUCTION}

Hypercalciuria means an excessive urinary calcium excretion greater than normal levels for age. Hypercalciuria is considered idiopathic (IH) when it is associated with a normal blood calcium level. ${ }^{1}$ This disorder affects $5-10 \%$ of the pediatric population ${ }^{2}$ and is usually related to a family history oflithiasis. $^{3}$

a. Division of Nephrology, Hospital General de Niños "Dr. Ricardo Gutiérrez" Buenos Aires, Argentina.

Miguel Liern, M.D.: Jliern@yahoo.com

Conflict of interest: None

Received: 08-09-2012 Accepted: 11-09-2012
2. To describe the occurrence of renal lithiasis, hematuria, urinary tract infection and osteopenia in relation to the variation of urinary calcium.

\section{MATERIAL AND METHODS}

An observational and retrospective study was conducted on patients older than 4 years with $\mathrm{IH}$, sphincter control, a normal estimated glomerular filtration rate, and absence of urinary tract diseases. The study was approved by the Ethics and Research Committee of Hospital de Niños Ricardo Gutiérrez (year 2012).

Exclusion criteria included hyperparathyroidism, hyperthyroidism, renal tubular acidosis, spinal and cranial dysraphisms, chronic renal failure, a recent period of prolonged immobilization, chronic bone disease, and intake of drugs that affect mineral metabolism (corticosteroids, diuretics, anticonvulsants, etc.).

IH was defined as a urinary calcium value greater than $4 \mathrm{mg} / \mathrm{kg} /$ day with a normal blood calcium level. The following lab tests were performed for diagnosis:

Blood: venous acid-base status, ionogram, uremia, magnesemia, glycemia, phosphatemia, uricemia, creatininemia by enzymatic method (estimated glomerular filtration rate using Schwartz's method) and parathyroid hormone determination.

A fresh urine sample was used to measure urine $\mathrm{pH}$, and a 24 hour urine sample was collected to measure calciuria, urea, citraturia, oxaluria, magnesuria, glycosuria, phosphaturia, uricosuria, ionogram and creatininuria.

The following diagnostic tests were initially requested to study associated diseases: kidney and gallbladder ul- 
trasound, urinary sediment evaluation, bag urine culture and bone densitometry (bone mineral density [BMD]) of the lumbar spine; for the diagnosis of a low bone mass, it was defined as a $\mathrm{Z}$ score of bone mineral content equal to or lower than -2 standard deviations adjusted for age, gender, body size and degree of development (Tanner stages). ${ }^{6}$

Extraglomerular hematuria was defined as the presence of 5 or more RBCs per high-powered field in two out of three weekly urine samples, with $<20 \%$ of dysmorphic RBCs and absence of G1 cells or acanthocytes.

A sequential treatment was implemented with quarterly interventions if hypercalciuria and any of the associated diseases persisted.

Phase 1: Diet (from month 1 to month 3 inclusive) 1.a. Water intake: $30 \mathrm{~mL} / \mathrm{kg} /$ day, in children aged 4-10 years old, and over 2 liters in adolescents.

1.b. Low sodium content ( $<6 \mathrm{~g} /$ day).

1.c. Normal protein level diet, varying from 0.8 to $1.2 \mathrm{~g} / \mathrm{kg} /$ day, depending on gender and age. ${ }^{7}$ Compliance was checked by means of three different mechanisms:

a) A nutritional survey administered to the patient (if possible) and his/her parents.

b) Estimation of protein intake based on the urea level in a urine sample collected in 24 hours and using the following formula:

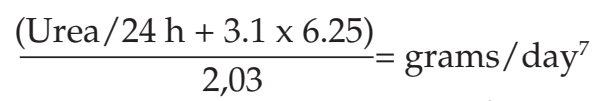

c) Urinary ionogram: $17 \mathrm{mEq} / \mathrm{L}$ urine sodium $=1 \mathrm{~g}$ of sodium intake a day.

\section{Phase 2: Potassium citrate 1-1.5 mEq/kg/day} (from month 4 to month 6 inclusive)

\section{Phase 3: Hydrochlorothiazide 1.5-2.5 mg/kg/day} (adding amiloride to patients with potassium level lower than $3.5 \mathrm{mEq} / \mathrm{L}$ ) (from month $7 \mathrm{on}$ ).

Patients underwent the following quarterly checkups:

1.a. Clinical: height, blood pressure (values were considered normal depending on the height and age percentiles).

1.b. Lab: 24-hour calciuria, urine culture, urinary sediment.

A kidney and gallbladder ultrasound was performed every six months, and a bone densitometry was done annually.
This review took place in the period comprised between August 2006 and August 2011.

\section{Statistics}

1) Exposure-associated risk (EAR) of $\mathrm{IH}$.

2) Relative risk (RR).

3) Turkey's procedure: to evaluate the effect of treatment intervention between 2 paired means in the same population.

4) $\mathrm{IH}$ incidence rate (person-time).

5) $\chi^{2}$ test with Yates' correction.

6) Number needed to harm (NNH).

7) Percent calculation of family members with hypercalciuria or nephrocalcinosis or kidney stones.

The statistical significance level was established at $p<0.05$.

Results were presented as means \pm SD and the statistical software GraphPadinStat was used.

The protocol was approved by the hospital's Ethics and Research Committee.

\section{RESULTS}

A total of 46 patients (18 females) were included; their mean age was 8 years old ( $r=4$ to 15 years old), they were eutrophic, with a urinary calcium excretion level greater than $4 \mathrm{mg} / \mathrm{kg} /$ day, normal urinary excretions and a normal blood calcium level (Table 1).

The mean follow-up time was 43 months ( $r=22$ to 60 months).

The two main reasons for consultation were gross hematuria $(43 \%)$ and urinary tract infection $(26 \%)$. Associated diseases were lower urinary tract infection (EAR 57\%; RR 3; 95\% CI 1.1-7.8); hematuria (EAR 71\%; RR 2.5; 95\% CI 1.2-5.1), and kidney stones (EAR 47\%; RR 3.3; 95\% CI 1.110). Eventually, 5 out of the 22 patients who underwent a bone densitometry had a reduced bone density (EAR 33\%; RR 3; 95\% CI 1.7-1.8) (Table 2).

A reduction in urinary calcium excretion was observed with the sequential treatment(Figure 1). Turkey's procedure: $p<0.001$.

Thirty-two patients discontinued treatment indications 2.7 times in average (86.4 total events), which accounts for an incidence rate of 53/100 persons/year; IH recurred temporarily in $38(44 \%)$ of non compliant patients (NNH 3.3) and there were 19 recurrent episodes of hematuria and 15 of urinary tract infections (Yates' correction $6.5 ; p=0.01$ ).

The percentage of affected parents or siblings was $62 \%$ (.72/f 108). 


\section{DISCUSSION}

An association between the reduction of urinary calcium and the frequency of concurrent diseases was observed in patients; some of these diseases (hematuria and urinary tract infection) recurred when treatment was discontinued.

In general, $\mathrm{IH}$ can be accompanied by different clinical conditions, including hematuria, urinary tract infection, kidney stones, dysfunctional micturition syndrome, recurrent abdominal pain, and even bone mass reduction.

Dysfunctional voiding (urinary incontinence, urgency and nocturia with no anatomical nor neurological abnormalities) was not considered ${ }^{8}$ given the subjectivity of its symptoms. In any case, irreversibility of nephrocalcinosis prevented us from evaluating its changes in relation to $\mathrm{IH}$ and, even though abdominal pain was one of the reasons for consultation, it was not regarded as a concurrent disease because of its multifactorial characteristics.

Extraglomerular hematuria, typical of urinary tract conditions, ${ }^{9}$ and urinary tract infection were the two prevailing clinical manifestations and they even occurred simultaneously; some patients had overlapping of both clinical conditions. IH could be considered as a predisposing factor for such a situation because the attachment of cal-

TABLE 1. Metabolic characteristics of the population diagnosed withidiopathic hypercalciuria

\begin{tabular}{|c|c|c|c|}
\hline \multicolumn{2}{|c|}{ Number of patients: 46} & \multirow[t]{2}{*}{ Patient values (mean \pm SD) } & \multirow[t]{2}{*}{ Normal values $^{7}$} \\
\hline Gender & $\begin{array}{l}\text { Male: } 28 \text { patients } \\
\text { Female: } 18 \text { patients }\end{array}$ & & \\
\hline & Calcemia (mg/dL) & $9.1( \pm 0.8)$ & $8.8-10.8$ \\
\hline & PTHi (pg/mL) & $49( \pm 9)$ & $10-72$ \\
\hline & Creatininemia (mg/dL) & $0.65( \pm 0.1)$ & Percentile per gender and height \\
\hline & $\operatorname{ALP}(\mathrm{IU} / \mathrm{L})$ & $510( \pm 118)$ & $145-560$ \\
\hline & Serum $\mathrm{pH}$ & $7.39( \pm 0.09)$ & $7.35-7.45$ \\
\hline & Urine $\mathrm{Na}(\mathrm{mEq} / \mathrm{kg} /$ day $)$ & $4.9( \pm 15)$ & $3.87(r=2.5-5.17)$ \\
\hline & Citraturia (mg/kg/day) & $5.5( \pm 0.9)$ & $9.6(r=5.5-3.6 \mathrm{mg} / \mathrm{kg} /$ day $)$ \\
\hline & Oxaluria (mg/kg/day) & $2( \pm 0.7)$ & $36.9\left(r=23.2-50.6 \mathrm{mg} /\right.$ day $\left./ 1.73 \mathrm{~m}^{2}\right)$ \\
\hline & Glycosuria (mg/dL) & Negative & Negative \\
\hline & Magnesuria (mg/kg/day) & $3.5 \%( \pm 1)$ & $2.1(r=1-3.2)$ \\
\hline & Urea FE & $9 \%( \pm 2)$ & $7.25(r=4.27-10.23)$ \\
\hline & Phosphorus FE & $11 \%( \pm 2)$ & $<15 \%$ \\
\hline & Urine $\mathrm{pH}$ & $5.5( \pm 0.1)$ & $5.5-6$ \\
\hline
\end{tabular}

PTHi: parathyroid hormone; FE: fractional excretion. All values are expressed as means \pm SD.

TABLE 2.Variation in the number of diseases associated with hypercalciuria and its relation to the therapy implemented

\begin{tabular}{|c|c|c|c|c|c|c|c|c|}
\hline \multirow[t]{2}{*}{$\begin{array}{l}\text { Associated } \\
\text { diseases }\end{array}$} & \multicolumn{2}{|c|}{$\begin{array}{l}\text { Patients with associated } \\
\text { clinical events at the } \\
\text { beginning and at the } \\
\text { end of the study }\end{array}$} & \multicolumn{3}{|c|}{$\begin{array}{l}\text { Indicated sequential therapy } \\
\text { and number of patients } \\
\text { with reduced associated } \\
\text { diseases in each phase }\end{array}$} & \multicolumn{3}{|c|}{$\begin{array}{l}\text { Percentage of } \\
\text { calciuria reduction }\end{array}$} \\
\hline & Beginning & End & LSD & $\begin{array}{l}\text { LSD+PC } \\
\text { (amiloride) }\end{array}$ & $\mathrm{LSD}+\mathrm{PC}+\mathrm{HTZ}$ & Pre & Post & $\begin{array}{c}\text { Calciuria } \\
(\mathrm{mg} / \mathrm{kg} / \text { day })\end{array}$ \\
\hline Lithiasis & 5 & 1 & 1 & 2 & 1 & 7.2 & 3.1 & $57 \%$ \\
\hline \multicolumn{9}{|l|}{ Extraglomerular } \\
\hline hematuria & 13 & 2 & 7 & 2 & 2 & 5.5 & 2.8 & $49 \%$ \\
\hline UTI & 15 & 4 & 8 & 1 & 2 & 5.8 & 3 & $48 \%$ \\
\hline UTI + hematuria & 7 & 2 & 3 & 2 & 0 & 6.2 & 3.7 & $59 \%$ \\
\hline Reduced bone density & 5 & 3 & 0 & 1 & 1 & 7.2 & 4 & $45 \%$ \\
\hline
\end{tabular}

UTI: urinary tract infection; LSD: low sodium diet; PC: potassium citrate; HTZ: hydrochlorothiazide. 


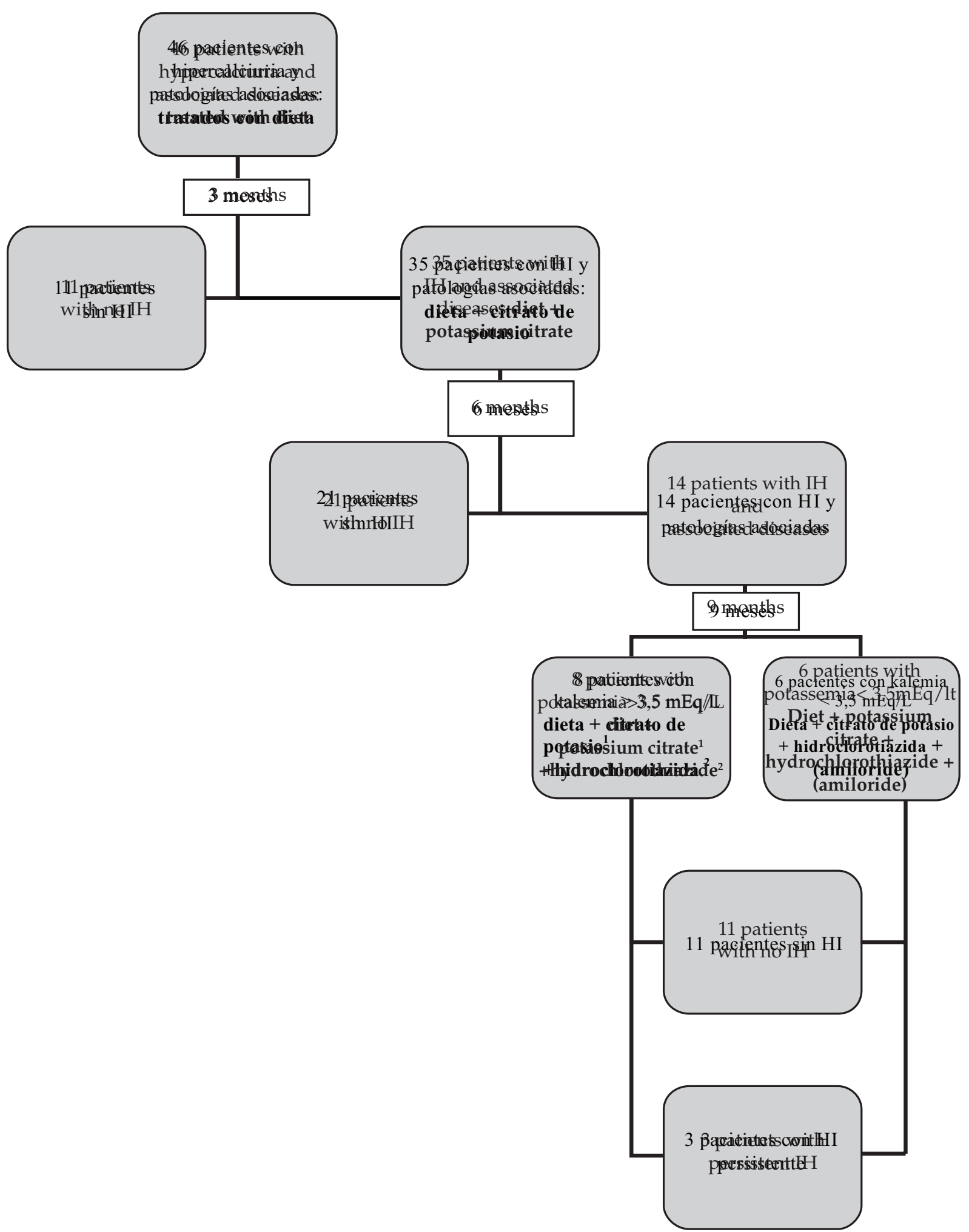

IH: idiopathic hypercalciuria.

The total number of patients achieving hypercalciuria reduction is indicated between brackets.

1: Average dose of potassium citrate: $1.6 \mathrm{mEq} / \mathrm{kg} /$ day $(r=1-2 \mathrm{mEq} / \mathrm{kg} /$ day $)$.

2: Average dose of hydrochlorothiazide: $1.3 \mathrm{mg} / \mathrm{kg} /$ day $(r=1-2 \mathrm{mg} / \mathrm{kg} /$ day $)$. 
cium oxalate microcrystals damages the epithelial cells of the uroepithelium, affects mechanisms of local defense and favors inflammation and renal tissue fibrosis. ${ }^{10}$

In our study, kidney stones occurred in $10 \%$ of the patients with $\mathrm{IH}$ and had a greater incidence than that reported by Ammenti ${ }^{11}$ although, in agreement with other experiences, it was found that this was the most common feature in adolescents.

In our population, osteopenia did not develop into bone and joint lesions and, as described by Penido, improvement in the $\mathrm{Z}$ score indicated a slow bone recovery process. ${ }^{5}$

A diet that is high in fluid, normal in protein and low in sodium intake was used considering its impact on hypercalciuria. ${ }^{12}$ Besides, potassium citrate treatment was supported by the formation of citrate-calcium complexes in urine, with a reduction of ultrafiltrable ionic calcium. ${ }^{13}$

Finally, and even though there are controversies in this respect, ${ }^{14}$ hydrochlorothiazide was used to stimulate transcellular calcium transport if IH symptoms persisted, consistent with La Croix's experience. ${ }^{15}$

In short, sequential therapy was found to be effective to manage $\mathrm{IH}$ and was related to a reduction of associated diseases.

\section{REFERENCES}

1. García Nieto V, Luis Yanesa MI, González Cerrato S. Fisiopatología de la hipercalciuria idiopática. Arch Latin NefrPed 2010;10:90-7.

2. Butani L, Kalia A. Idiopathic hypercalciuria in children- how valid are the existing diagnostic criteria? PediatrNephrol 2004;19:577-82.

3. Stechman M, Loh N, Thakker R. Genetic causes of hypercalciuric nephrolithiasis. Pediatr Nephrol 2009; 24:2321-32

4. Pak CY, Kaplan R, Bone H, Townsend J. Simple test for the diagnosis of absorptive, resorptive and renal hypercalciuria. N. Engl J Med 1975;292:497-500.

5. Penido MG, Diniz JS, Moreira ML, Tupinambá AL. Idiopathic hypercalciuria: presentation of 471 cases. J Pediatr 2001;77:101-4.

6. Bachrach LM, MD. Osteoporosis and Measurement of Bone Mass in Children and Adolescents. Endocrinol Metab Clin N Am 2005;34(3):521-535

7. Nefrología Pediátrica. Buenos Aires: Sociedad Argentina de Pediatría; 2003. Págs. 700-36.

8. Kearney S, Haralam M, Colborn D. Dysfunctional Elimination Syndrome: Is It Related to Urinary Tract Infection or Vesicoureteral Reflux Diagnosed Early in Life? Pediatrics 2003;112:1134-7.

9. SchrameckP, Schuster FX, Georgopoulos M, Porpaczy P, MaierM. Valueof urinary erythrocyte morphologyin assessmentofsymptomlessmicrohaematuria.Lancet 1989;2: 1316-9.

10. Stojanovi V, Miloševi B, Djapi M. Idiopathic hypercalciuria associated with urinary tract infection in children. PediatrNephrol 2007;22:1291-5.

11. Ammenti A, Neri E, Agistri R. Idiopathic hypercalciuria in infants with renal stones. PediatrNephrol 2006;21:1901-3.

12. Osorio VA, Alon US. The relationship between urinary calcium, sodium and potassium excretion and the role of potassium in treating idiopathic hypercalciuria. Pediatrics 1997;100:675-81.

13. Ettinger B, Pak C, Thomas C. Potassium-magnesium citrate is an effective prophylaxis against recurrent calcium oxalate nephrolithiasis. Journal of Urology 1997;158,2069-3.

14. García-Nieto V, Monge-Zamorano M, Yanes M. Effect of thiazides on bone mineral density in children with idiopathic hypercalciuria. PediatrNephrol 2012;27:261-8.

15. LaCroix AZ, Ott SM, Ichikawa L, Scholes D, Barlow WE Low-dose hydrochlorothiazide and preservation of bone mineral density in older adults. J Clin Endocrinol Metab 2000;57:920-4. 